\title{
The Deconsolidation of Democracy in East-Central Europe: The New World Order and the EU's Geopolitical Crisis
}

\author{
ATTILA ÁGH
}

$\frac{\text { DE }}{\text { G }} \stackrel{\text { DE GRUYTER }}{\text { OPEN }}$

Politics in Central Europe (ISSN: 1801-3422)

Vol. 12, No. 3

DOI: $10.1515 /$ pce-2016-0015

\begin{abstract}
In recent decades, the most remarkable feature of East-Central European (ECE) states has been their engagement in a deconsolidation process that necessitates the reconceptualising of European Studies and the theory of democracy. In the early'90s, during the "revolution of high expectations," consolidation was the key term in the conceptual framework of the transitology paradigm, but this approach was questioned increasingly in the 2000s and rejected in the 2010s. In its place, deconsolidation was introduced as one of a wide array of similar terms referring to the decline, backsliding or regression of democracy and later as one of a whole "other" family of opposite terms like (semi-)authoritarian system and competitive/elected autocracy. Indeed, rather than a transition to democracy, a tendency to transition to authoritarian rule has been observed in the ECE states in general and in Poland and Hungary in particular. In the last quarter century, the twin terms of Europeanisation and democratisation, which denote normative approaches, have been the main conceptual pillars of analyses of the ECE states. It turns out, however, that the opposite processes of de-Europeanisation and de-democratisation can now also be observed in these countries.
\end{abstract}

Key words: democracy, deconsolidation, East-Central Europe, geopolitical crisis, EU

In fact, the systemic change in East-Central Europe took place during the Old World Order (OWO) between 1989 and 2014. In contrast, the New World Order (NWO) since 2015 has introduced new global rules and created a new international environment for ECE domestic developments. This article therefore 
proceeds on two levels and via two conceptual frameworks: it begins by offering a theory of the deconsolidation process in the ECE countries of the EU during the OWO stage and then describes the new conceptual framework for ECE in the NWO stage. The first part discusses internal deconsolidation while the second part deals with external deconsolidation, looking briefly at the EU's global role and analysing the EU's regionalisation process as a "nested" game in the ECE region. During the current "polycrisis" in the EU, a two-sided process of securitisation and de-securitisation has also taken hold within ECE due to the return of geopolitics with the refugee crisis. The first half of this article, thus, takes a triple crisis in the Old World Order as its point of departure while the second half responds to the de-securitisation of ECE states in the New World Order. Finally, in an effort to attain a more positive outlook, I outline some perspectives on re-democratisation as a bottom-up process that could replace today's failed top-down democracies imposed by elites.

\section{Introduction: The age of uncertainty in democracy studies}

In the good old days, everything was clear according to a "simple dichotomy" between democracy on the one hand and autocracy or authoritarian systems on the other (Merkel 2004: 33). As democracy has declined in East-Central Europe (ECE), the response in the academic literature has become more and more uncertain and chaotic. Democracy is increasingly qualified with adjectives like "electoral," "minimalist," "populist" and "defective," and this has also been necessitated by special developments in individual ECE countries. Nowadays, the ECE countries are caught "in between," i.e. in a space somewhere between democracy and non-democracy and in systems which have slipped in the last few years from semi-consolidated democracies into "flawed democracies" (FH $2016 \mathrm{a}, \mathrm{b})$. Although this historical trajectory of deconsolidation has been described extensively in the international scholarship, it remains highly contested among ECE academics due to acute national sensitivities and the apologist efforts of incumbent governments. Political scientists internationally have discussed the ECE region in terms of declining democracy since at least 2007 when the Journal of Democracy published a special issue on the topic ("Is East-Central Europe Backsliding?”; see Rupnik 2007) and the debate has continued in special issues of that journal, most recently under the heading "Is Democracy in Decline?" (2015). Based on these overviews, it appears that the common historical trajectory of democracy's decline in ECE can best be summed up by the term deconsolidation. ${ }^{1}$

1 I have dealt with the internal deconsolidation process in ECE in earlier works (Ágh 2015a, b,c). This article tries to locate this issue in the context of the latest developments. It takes as its background 
This deconsolidation has been confirmed and well-documented by major ranking institutions including the Bertelsmann Foundation (BF), The Economist Intelligence Unit (EIU) and Freedom House (FH, with Nations in Transit, NIT Reports) year after year. At a glance, there has indeed been a growing gap between formal and substantive democracy since the very beginning of the systemic change period. Thus, despite national sensitivities in ECE countries and the apologist views of loyal experts to national governments, inventories of the health of these countries have suggested a serious socio-economic and political crisis based on the converging assessments of all relevant international policy institutions. At the same time, the international media have reported on election landslides, major corruption scandals and the symptomatic actions of oligarchs in and around these ECE governments. These events have been accompanied by the declining popularity of ECE parties and governments and the increasing apathy, mass protests, radicalism and Euroscepticism of the population, generating a huge gulf of trust between the elite and citizens. Loyal ECE analysts may close their eyes to these developments and minimise them and/or only list the achievements, but this is also the reason why the "lack of the deep substance of democracy remains largely and voluntarily unobserved" in ECE (Papadopoulos 2013: 2). ${ }^{2}$

All in all, it is rather difficult to find a proper term for these hybrid polities between democracy and non-democracy in ECE. As a result, political scientists studying the democratisation and Europeanisation of ECE countries have entered an age of uncertainty. Big problems surround definitions of democracy, which vary depending on whether assessments of recent developments are positive/optimistic or negative/pessimistic. Many new terms have been circulated that apply fundamentally different - thin and thick - criteria for democracy and result in contradictory evaluations. Mainstream analyses have used polite terms, referring to "hybrid," "deficit" or "half" democracies since some negative issues are too glaring to ignore, particularly when they affect ECE parties and party systems. Increasing corruption and decreasing trust in politics and politicians have already been observed superficially (EC 2014b), but in most cases, these issues have been addressed separately and not in terms of their organic connections as systemic features demonstrating the profound decline of the new democracies. In order to avoid negative evaluations, many studies fall back on a minimalist definition of democracy based on electoral democracy

the New World Order and the recent authoritarian turn in Poland, presenting Poland and Hungary as trendsetters.

2 For detailed data about this deconsolidation process, see the Annex to this study; I return to this material in what follows. This article focuses on ECE countries. While the first part also applies to all new member states (NMS) mutatis mutandis to a large extent, there is no space here to comment on the idiosyncrasies distinguishing ECE from wider NMS developments. In the second part, I focus on the drastic transformations of New World Order, which affect the NMS as a wider region more fully and directly. 
with its "free" elections and some basic human rights. Supposedly, this allows these polities to qualify as democracies but at the high price of ignoring the "unfair," illusory and non-representative nature of their elections (OSCE 2014) and the actual socio-political exclusion of large communities, which prevents them from enjoying their "individual freedoms."

In order to legitimise their regimes, many (soft) dictatorships also permit some sort of manipulated and/or controlled election process which results in elected autocracies or competitive authoritarianisms. Given the fact that today's dictatorships may embrace some core elements of democracy, while democracies may be hollowed out by developing some authoritarian features, the under-theorisation of democracy and dictatorship is particularly clear. It is no longer enough to separate these two main forms of regime in a simple way for analytical purposes, i.e. describing democracy as merely the opposite of dictatorship. Since standard analyses often lack the traits of a holistic or systemic approach, the theory of democracy needs a new system for defining both democracies and non-democracies based on a detailed theoretical understanding that captures all the sub-types in between. At the same time, the only way to systemise democracies and dictatorships and all their hybrid variants and sub-types is to infuse nuance and/or substance into the earlier radical and mutually exclusive distinction between democracies and dictatorships. The systematisation also implies developing a conceptual framework for the emergence of deconsolidation as a process. Earlier studies focused only on the transition to democracy but today's system must include the transition from democracy to authoritarian rule. The various regimes representing sub-types must also be geographically (regionally) clustered, e.g., for the ECE countries (for a recent account, see Lidén 2014: 50, 53). ${ }^{4}$

Nevertheless, in this age of uncertainty for democracy studies, experts have hardly considered that the "democratisation" resulting in deconsolidation took place under the Old World Order (OWO). This systemic change in ECE began in the early' 90 s and was accomplished over the last quarter century under favourable conditions. In contrast, the ECE's historical trajectory is now proceeding under the drastically different and unfavourable conditions of the New World Order (NWO). EU accession has been both an opportunity and a challenge, functioning in very different ways under these changing world orders: while the OWO offered a great opportunity, the NWO presents a severe challenge. The

3 To mark the occasion of ten years of EU membership, special issues of several journals reviewed the decline of ECE democracies and the shift to authoritarian rule. See East European Politics and Society (Rupnik-Zielonka 2013), Journal of Common Market Studies (Epstein - Jacoby 2014) and East European Politics and Societies and Cultures (Banac 2014).

4 The new ECE authoritarian regimes are usually presented in international politics and media as "illiberal states," a term advanced by Orbán (2014).[Alternative wording/meaning here: states,"as Orbán (2014) observes.] 
"polycrisis" in the EU under the NWO has led to an increasing core-periphery divide, which threatens to marginalise the ECE region further and portends future conflicts between ECE and central EU institutions. ${ }^{5}$

In general, European governance needs to be analysed from the twin perspectives of multi-level governance (MLG, the institutional-territorial-regional dimension) and multi-dimensional governance (MDG, the coordination of policy development dimension). If we take an inward-looking approach, the deconsolidation process can also be described by way of these two dimensions. The first considers the socio-economic and political history of the last quarter century according to a conceptual framework of "triple transition - triple crisis," which has led to three debates about democracy. The second analyses ECE's different integration, i.e. the region's divergence from mainstream EU developments based on what may be summarised as de-Europeanisation and de-democratisation processes (in these polities, politics and policy structures serve as negative, elitist and regressive forms of integration). The point of departure for the first aspect of this inward-looking approach is the Dahrendorf-Offe "trilemma" between political, economic and social systemic changes in ECE. In the second half of this article, I address the deconsolidation process using an outward-looking approach that refers to the EU polycrisis (Juncker 2016) due to the incoming New World Order. This analysis first approaches deconsolidation as some kind of domestic socio-economic and political de-securitisation process. It then turns to emerging tensions between the transnational and member state levels based on increasing security debates. I, thus, examine the resulting danger that the ECE region may become its own sunken continent.

\section{The inward-looking approach: ECE's historical trajectory under the Old World Order}

\section{Triple transition and triple crisis: Three democracy debates}

Triple transition and triple crisis are key concepts for understanding the present social and political situation in ECE. The ECE countries first underwent a triple transition of their economies, polities and societies and later experienced a triple crisis as three profound socio-economic crises morphed into a political crisis over the last quarter century under the OWO. These countries went through a transformation recession in the early ' 90 s and then fell into a post-accession

5 I address the external deconsolidation process as a new field of research elsewhere (Ágh 2016 a, b,c). This new conceptual framework has just begun to enter European Studies. As one Bruegel analyst notes, the major Eastern crisis of an expansionist Russia and declining Eastern Partnership region came as a surprise to the EU since Europeans appear to have lost the habits and expertise required to analyse the world in geopolitical terms during the relatively relaxed multi-polar era (Biscop 2015: 2). The edited volume by Magone et al. (2016) provides a comprehensive analysis of core-periphery relations under the NWO. 
crisis on their EU entry in the 2000s, which was quickly followed by the global crisis later in the decade. In sum, these states have paid a very heavy social price for their political and economic transformation during the triple transition. The original assumption in the early ' 90 s had been that the three - political, economic and social - dimensions of the democratic transition would create a virtuous circle and reinforce each other. The triple crisis, however, unleashed a vicious circle in which these dimensions increasingly - and fatally - weakened one another. The negative outcomes of the triple transition, known as the "Dahrendorf effect" and based on the diverging timing and controversial processes of the various spheres of this systemic change (Dahrendorf 1990), were observed as early as the ' 90 s by public commentators as well as academics. In an often quoted analysis, Ralf Dahrendorf explained that political-legal transformation requires about six months while economic transformation takes six years and social transformation 60 years. Claus Offe (1991; see also Offe - Adler 2004) also warned of the dangers of taking a simplistic approach to triple transition, pointing out the virtual contradictions between political-legal, economic and social transformations. ${ }^{6}$

The Western fallacy had held that the Western road from democratisation to consolidation could be replicated in ECE, producing the same macro- and micro-structures of liberal democracy and a vibrant civil society. Consolidated democracies had, however, emerged in Western Europe after World War II based on a solid foundation of socio-economic development following three decades of rapid economic growth; Western civil society was the product of even longer term historical developments. Despite all warnings to the contrary, advocates of an Eastern carbon copy of the Western model maintained that liberal democracy would thrive in ECE immediately after the establishment of large formal democratic institutions. For a long time, the Dahrendorf and Offe exhortations were neglected and the naive optimism of the Western fallacy prevailed, with experts arguing for the success of a catch-up process. Although the negative historical trajectory of deconsolidation was already apparent to some extent in the early 2000s, these worries were swept away by EU-euphoria and over-optimism that EU membership with all its "automatic" effects would resolve the basic contradictions between and within economic, political and social developments. Proponents maintained that the ECE region was an "emerging continent" soon to join the core of developed countries and consolidated democracies.

The idea of "sustainable" democracy had come to the fore of political science debates in the '90s (Przeworski 1995) when the future of ECE democracies was called into question within the third wave of democratisation. Up to that point,

6 Data about the triple crisis are readily available. See the large databases of Bertelsmann Foundation (BF) (2015a, b), the European Catch Up Index (2014), International Labour Organization (2016), Freedom House (FH) (2016a, b) and World Economic Forum (WEF) (2015), among others. 
the eco-left literature had only emphasised that democracy was needed for sustainable - ecological and social - developments. However, from the '90s onwards, more and more stress was put on the opposite argument that sustainable economic and social development was essential for sustainable or "consolidated" democracy. Despite emerging signs of a vicious circle between political, economic and social systemic change, EU documents continued to present the history of democratisation and Europeanisation in ECE as overwhelmingly a success story or sunny-side narrative. In a similar way, mainstream Western theories and most ECE experts tended to describe the ECE transformation as basically an evolutionary process, i.e. without special attention to the increasing contrast between the presence of formal-legal democratisation and the lack of social consolidation. These commentators were typically unwilling to give up a formalistic-legalistic approach to democratisation and they failed to detect that increasing social disintegration and fragmentation were the main drivers behind political crises.

The global crisis ultimately exposed the weak development of the semi-periphery of the EU, and after ten years of membership, malaise about democracy became the dominant mood in ECE with a populist turn and growing Euroscepticism. Back in the early 2010s, a European Policy Centre (EPC) analysis had warned that countries like Poland, Slovakia, Hungary and Czech Republic appeared to take a "populist turn," suddenly calling into question the hitherto linear reading of democratisation which presumed a cumulative and irreversible progression of the CEE democracies from transition to consolidation. Fast-forwarding to the present day, against the backdrop of the crisis, the incidence of threats to the EU's democratic principles and values has increased (Balfour and Stratulat 2012: 2).

From a present-day vantage point, it is undoubtedly difficult to strike a balance between positive and negative features when describing this process of democratisation and social disintegration. Nevertheless, marked signs of socio-economic and political crisis in recent times call for the presentation of a darker narrative about the deconsolidation of ECE democracy. A very large-scale recent debate about anti-democratic tendencies and democratic regression in ECE has come to the conclusion that democracy should not be taken for granted in ECE countries. In fact, it is useful here to consider three other discussions about democracy which have been taking place among international political scientists in parallel with the triple crisis in ECE. These debates are very helpful for understanding ECE developments in general since their redefinitions of democracy mirror the radical shift of attention in ECE from the "political" to the "social" history of democratisation and from a consolidation to a deconsolidation paradigm. ${ }^{7}$

7 Rupnik and Zielonka (2013) point out that the academic literature has focused on political-legal issues or macro-politics in ECE and neglected the social and cultural dimensions. In the same spirit, Gergana 
These debates about democracy have been organised around the three main themes of transition, consolidation and quality of government (Denk - Silander 2012: 26). The first set of discussions took place in the ' 90 s with participants describing sharp regional differences in the democratisation process in a rather optimistic mood. These commentators maintained that after an initial transition period of dynamic ECE democratisation, democratic consolidation would follow, bringing about the homogenisation of the new social system as a whole; in contrast, in the controversial East European (EE) version of democratisation, only semi-democratic systems would emerge. The main divide was, thus, between ECE "democracies in the making" on one side and special EE forms of half-democracy on the other, with this "reverse wave" producing new semi-authoritarian regimes. While the focus of this first debate was on the legal-formal institutionalisation of democracy, in the second debate, it shifted to a more complex analysis of democracies based on many social and political indicators. In the 2000s, the evolutionary development of ECE was called into question when it emerged that consolidation had been delayed or become doubtful. Hybrid democracy was used as an analytical device to explain this situation since the heterogeneity of social and political transformations remained the best analytical concept to account for ECE in the 2000s (Bogaards 2009; Cassani 2014; Coppedge et al. 2011; Dzihic 2014). On this basis, commentators tried to explain why after profound political and economic transformations, social systemic change had been delayed in the ' 90 s and later failed in the post-accession crisis of the 2000s. That failure meanwhile generated widespread public discontent and its repercussions undermined popular support for democracy to a great extent. The second generation of theories still drew a vital distinction between the embedded or "deficit" democracies of ECE and the semi-authoritarian regimes or "defect[ive]" democracies of EE (Merkel 2004). Nonetheless, among those in a more pessimistic mood, the weakening of ECE democracy was already being discussed in the larger context of the "backsliding" of democracy in ECE (see, e.g., Rupnik 2007), with some even predicting deconsolidation. ${ }^{8}$

Noutcheva (2016) has recently argued that mainstream literature emphasises the major role of the transfer of big formal institutions in the Europeanisation of the NMS; she notes, however, that these publications overlook the importance of "societal empowerment." It is no coincidence that BF has launched a Social Inclusion Monitor (SIM) project in Europe. In fact, social crisis is the most important new phenomenon since the global crisis, especially in ECE countries. In 2015, BF published its second report in this series (BF 2015c).

8 The "transition to authoritarian rule" approach grew out of a school of Nordic thought concerning the quality of democracy, an increasingly topical issue in the 2010s with the sensational return of authoritarianism worldwide. It was no coincidence that around this time the journal Democratization published its special issue "Unpacking Autocracies: Explaining Similarity and Difference" (edited by Köllner - Kailitz 2013). In a comprehensive book-length study of democracy, Papadopoulos (2013: 2-3) discusses a "hollowing-out of democratic politics" (with reference to Guy Hermet), which is very characteristic of ECE developments. Over the three debates, both the number of countries and the socio-political indicators considered were greatly extended. 
The third set of democracy debates, which began in the late 2000s, has embraced all states in the world and concentrated on the quality of democracy and social progress using a highly complex set of indicators described by many international ranking agencies. This larger discussion has uncovered the fundamental weaknesses of the ECE countries from the standpoint of global competitiveness. At the same time, it has become clear that the EU has produced not only positive but also negative externalities since the modernising effects of EU transnational actions often appear at the core and the setbacks on the periphery; this is the case for the Eurozone, for example. Since the global crisis, it has become more apparent than ever before that the tremendous changes in ECE have not come organically from inside but arrived from outside as a tsunami or "imported crisis." In particular, the ECE transformation crisis arose from the collapse of the East-West confrontation in a bipolar world, the post-accession adjustment crisis was generated by the EU entry process, and finally, the crisis over competitiveness broke out due to the global fiscal crisis. A second point of discussion has been the entirely half-baked and controversial reactions of ECE countries to these external challenges. The democratic transition was not properly completed because both "anticipatory" Europeanisation and later "adaptive" Europeanisation remained unfinished, and the global crisis, thus, exploited the vulnerability of the ECE countries. These states either responded to the EU's moves with national resistance to structural reforms due to reform fatigue or they only adopted placebo reforms and so ensured non-compliance instead of effective compliance. In sum, the EU has had only a limited impact on these new member states because they have neutralised the Europeanisation pressure. It is no accident that these countries have been poor at managing the global crisis; after all, the recent "statocracy" system and "new nomenclatura" have not fostered any crisis resilience given the poor governance and fragile governments in ECE. ${ }^{9}$

Rejecting the idea of "rapid democratic consolidation" in ECE (see Merkel 2008), many recent publications have, thus, focused on re-evaluating the post-communist success story. In a special issue of Europe-Asia Studies, Ramona Coman and Luca Tomini (2014) specifically analyse the development of scholarship about the ECE countries. Pointing out the general trend of democracy's decline in their introduction, these authors conclude that the most important question today is "How can we explain the democratic crises in the new member states [?]" (2014: 855). This key task is also identified in the title of Tomini's contribution "Reassessing Democratic Consolidation in Central and Eastern Europe and the Role of the EU." The backsliding of democracy or "democratic regression" has indeed come as a surprise to most analysts, who

9 This third democracy debate provides the general background for recent analyses by ranking institutions. I return to this debate further on with reference to the WEF data contained in the Annex. 
defined democratisation very narrowly, referring only to the establishment of big formal institutions in young democracies. As Lise Herman (2015) observes, minimalist definitions of democracy -based on the "procedural minimum" of the operation of big formal institutions - now have little explanatory power. Such well-designed formal institutions seemed to provide a guarantee against the erosion of democracy in ECE, however this thin democratic façade has crumbled without the support of a vibrant civil society and deeply ingrained democratic norms (Herman 2015: 4,9,13). The result is that the democracies of the elite have been eroded and a deconsolidation process is under way. ${ }^{10}$

\section{Deconsolidation in ECE as de-democratisation and de-Europeanisation}

Deconsolidation should also be described in terms of EU convergence and divergence since democratisation and Europeanisation are two sides of the same coin in the same way that the opposite processes of de-democratisation (De-Dem) and de-Europeanisation (De-EU) are. The convergence model was evolutionary and optimistic and it dominated the ECE literature for a long time. This explanatory model presupposed that despite some hesitation, weaknesses and partial setbacks, the ECE countries had basically converged with the EU through a catch-up process in economic, social and political terms. The divergence model, in contrast, is backsliding-focused and pessimistic, and it has recently become more influential. Maintaining that ECE countries have basically diverged from the Western trajectory, this innovative model treats ECE's controversial development as a specific kind of underdevelopment on the semi-periphery. As such, it holds that the EU membership of the ECE countries has merely reproduced the age-old East-West divide "at a higher level."11

Seen, then, as divergence from mainstream EU developments, the deconsolidation process can be measured and documented as a matter of differentiated integration (DI) across the "polity," "politics" and "policy" spheres. In fact, when it comes to polity DI, the Rome Treaty stipulates that only democratic European states may be members of the EU. There is no doubt that a variety of national models of European democracy can exist and this variety can be seen as positive

10 Poland and Hungary have been the trendsetters when it comes to both the transition to democracy in the late ' 80 s and the transition to authoritarian rule in the 2010s. This is quite clear from the latest country reports (see BF 2016a, b; FH 2016c, d; Pappas 2014). A FH Poland report notes that "[t] he year 2015 brought immense political change in Poland" and concludes that due to "the PiS' aggressive agenda (...) the state of Polish democracy will continue to deteriorate." (FH, Poland 2016b: 2-3).

11 There is a temptation among some comparative politics analysts to compare the ECE countries given their similar trends and key indicators. Poland has often been cited -especially by Polish authors - as an exception, but in fact it is part of the same regional trend. The Polish political system is analysed in very critical terms in a comprehensive paper by Rupnik and Zielonka (2013) as well as other more recent publications (see Aniol 2015). 
divergence. The EU has, however, only raised the issue of the ECE's negative divergence from democratic polity very belatedly since it has over-respected the "sovereignty" of new member states. ECE's negative divergence occurred long before the global crisis and there was no meaningful EU reaction. Moreover, due to the global crisis, the deconsolidation of democracy has since become widespread, producing an increasing gap in levels of democracy across the EU. Finally, European Parliament (EP), that guardian of democracy, has concluded that the regular violation of democratic European values is dangerous for the EU. In this way, it has recognised that the EU must pay a high price for neglecting ECE's negative divergence and over-respecting the principle of non-interference. In addition, EP has itself begun to take steps against some cases of negative divergence and declining democracy though so far this has only seen limited success. $^{12}$

The negative and regressive DI is also reflected increasingly in the realm of politics with decreasing rates of popular participation in ECE's domestic polities. These democracies of the elite have, in turn, weakened the voice of ECE countries in EU transnational decision-making bodies. In particular, there has been a split between the participatory democracies of the West and the non-participatory, "passive" democracies of the East. The EU28, thus, now represents far more than a "multi-speed" Europe; it is a "multi-floor" Europe since the positions of the different member states have already been institutionalised, i.e. rather strictly arranged and regulated legally, to a great extent. On this basis, even Poland only has partly effective membership at best while the other ECE countries have absolutely marginal membership.

The Copenhagen criteria stipulate the need for not only a democratic polity but also "competitive polic[ies]" since member states must have the capacity to withstand competitive pressure within the EU. Some degree of policy DI remains necessary in terms of socio-economic development because of the (growing) heterogeneity of the EU. In the case of policy, however, there is a difference between progressive divergence, which describes the creative capacity of DI to foster alternative developments, and regressive divergence, which is the failure to accommodate EU rules. Even progressive divergence, when applied as a policy for catching up with mainstream developments in an optimal way, has generated a lot of problems and complications. Nevertheless, in the final analysis, such divergence may prove helpful for EU members' common future if these transitory stages and forms lead to a more convergent EU. In contrast, regressive divergence refers to the refusal or avoidance of policies needed to adapt to the EU and/or to changing external conditions. This non-compliance

12 In July 2013, European Parliament, acting as a kind of guardian of democracy, accepted the Tavares Report, which showed that such violations in Hungary were of a systemic nature - that is, they pointed to a coherent anti-democratic system that the Hungarian government had designed and created. 
with the policy-oriented membership rules results in socio-economic backsliding and creates a widening competition gap.

Obviously, these three types of DI divergence are closely interrelated. They veer closest together in the preparation, execution and monitoring of the member states' strategic direction for socio-economic and political development. Due to the shallowness of their EU integration, "non-democratic" and "non-competitive" member states not only lag behind in quantitative results but also slide back qualitatively to a "low-performing" mode of development. It is important to point out that this polity-politics-policy DI has produced a profound divergence from mainstream EU developments with common features that can be described as deconsolidation in ECE. Such common divergence has generated another vicious circle of backsliding EU democracies which might have been detected before the global crisis and which that crisis has, in fact, very much intensified. This approach makes clear that basic divergence in even one country hurts the EU as a whole. Thus, in the spirit of the Copenhagen criteria, we can draw a contrast between well-performing "thick" democracies and low-performing "thin" democracies. As the guardian of treaties, the Commission has taken action in many cases of regressive divergence where direct rules exist. It has, however, been unable to go beyond this narrow understanding of the acquis since the strategic direction of socio-economic development has mostly remained under the competence of member states. ${ }^{13}$

This DI approach raises additional questions about two pairs of opposed processes: democratisation vs. de-democratisation (De-Dem) and Europeanisation vs. de-Europeanisation (De-EU). On this basis, a relative De-Dem and De-EU process would mean underperformance in the EU despite predominant convergence while absolute De-Dem and De-EU would describe a process in which divergence dominates across the polity, politics and policy fields. The relative De-Dem and De-EU position assumes that though the distance between East and West may be growing, the two still have a common target and are on the same road. In this scenario, an evolutionary-convergence model would still apply and the process might qualify as partial consolidation. Under absolute De-Dem and De-EU, on the other hand, even if new achievements arose in some fields, the basic historical trajectory would be one of divergence from mainstream EU developments in a vicious circle of deconsolidation.

Applying this understanding, we may conclude that in the first decade of systemic change, the relative De-Dem model and consolidation paradigm oper-

13 The European Commission has established a New Framework of the Rule of Law Initiative. This is, it notes, a response to "recent events in some Member States [which have] demonstrated that a lack of respect for the rule of law and, as a consequence, also for the fundamental values which the rule of law aims to protect, can become a matter of serious concern. [...] there is a systemic threat to the rule of law and, hence, to the functioning of the EU." While infringement procedures are triggered by "individual breaches of fundamental rights," the New Framework has been designed to address "threats to the rule of law [...] of a systemic nature" (EC 2014:2,5,7). See also Euractiv 2014. 
ated to some extent in ECE. After ten years of socio-economic destabilisation, however, the next decade brought increasing political destabilisation due to a populist movement that remobilised the relatively and absolutely disempowered. This increasing destabilisation of the political, economic and social arenas caused the partial deconsolidation of the overall system. Finally, in the third (and present) decade of change, ECE's lack of resilience to the global crisis has exposed the basic divergence between East and West as a clear case of absolute De-Dem with deconsolidation. Across the ECE region, more and more non-democratic features have emerged in situations of state/agency capture (Innes 2014), which, in my view, also represent full "democracy capture."

The capture of the state/agencies by business and party oligarchs has led to chaotic democracies and a relative paralysis of power within the ECE states. It has also tempted some to believe that a strong leader in a guided democracy or velvet dictatorship might restore law and order. In a state of captured democracy, a quasi-monopolistic central power uses formal democratic institutions as a mere Potemkin wall or democratic façade to legitimise their regime both internally and externally. After the long decade of Poland and Hungary's EU membership, leading EU politicians and experts have put these states in this category, declaring that these new trendsetters in the deconsolidation process would be rejected if they applied for membership today. These countries, they claim, have seriously violated European rules and values and so cannot be considered working democracies. ${ }^{14}$

\section{The outward-looking approach: The deconsolidation of ECE under the New World Order}

\section{The Eastern semi-periphery of the EU: ECE's internal deconsolidation under the NWO}

In the late ' 80 s and early '90s, theories based on long waves or Kondratieff cycles were very popular since it seemed convincing that systemic change would take place at the end of the "short 20th century." In fact, the world system did change drastically during the transition from a bipolar to a multi-polar system due to the collapse of the Soviet Union. The emerging world order determined the ruling social science paradigm with its optimistic outlook on global democratisation and its special ECE version, which was paired with the "return to Europe" in a process of democratisation and Europeanisation. For many, it was plausible that this was even a sign of the "end of history" based on a very simplified model of worldwide democratic victory. In the mid-2010s, however, the "new" world

14 Javier Solana (2016) has argued that EU membership applications by Poland and Hungary would be rejected today. Bill Clinton has called the incumbent Polish and Hungarian regimes "authoritarian dictatorship[s]" (quoted in Chadwick 2016). 
order unexpectedly turned into the "old" world order. Moreover, since that time, the social sciences have been unable to digest the new paradigm of returning geopolitics and securitisation which has worsened conditions worldwide for democratisation, including the Europeanisation of ECE. If we are to avoid the conceptual trap of theorising the current ECE situation in terms of the OWO, then it is crucial to situate these ECE developments in terms of the NWO. Having considered how the favourable conditions of the last quarter century gave these states an opportunity to catch up, I, thus, face the task of describing their starting position in the New World Order with a focus on new challenges.

The stages of world system development known as the OWO and NWO contain several periods. The final period of the OWO stage can be identified as the EU's transformation in the early 2010s in the wake of the global crisis. This turned into the most recent period of geopolitical crisis in the mid-2010s when the world system entered the NWO stage. If we are to take an outward-looking approach to the EU's global role after this world system change, then we need a new conceptual framework based on the twin paradigms of European governance. Concerning the first paradigm (i.e. policy development, MDG), the EU's traditional role as a civil superpower has been shattered under the pressure of new, complex and ever-increasing security challenges at the current stage of active globalisation. This new global situation calls for an urgent and coordinated securitisation response in the widest possible sense of security. As regards the second (institutional-regional, MLG) paradigm, the EU has had at the same time to respond to world system changes through a new "globalisation-cum-regionalisation" form of action. This has entailed the drastic reform of its own mega-region through the use of new kinds of macro-regions both inside and outside the Union for the territorialisation-localisation of European governance. ${ }^{15}$

The global crisis has weakened the EU on both these fronts. The EU has not yet resumed its trajectory of sustained economic growth in the face of global competition and nor has it been able to play its former influential role in the world system. These routes are barred since the EU's old civil superpower profile does not enable multi-dimensional governance (MDG) in a complex multi-level security system (MLG). Going beyond classical notions of "economic Europe," the EU needs to (re-)organise and coordinate an "energy Union" and a "digital Union," and even more pressingly, a "security Union" (the latter seems to be falling apart, at least in the current transitory situation of the emerging NWO). The ECE region has suffered even more intensely from both these weaknesses of European governance. The pressures of the global crisis and its aftermath have

15 Management of the Eurozone crisis was the key issue during the EU's transformation crisis. This management was more or less achieved though it remains incomplete. Concerning the pending geopolitical security crisis, the main issue is the completion/reform of the incomplete and fragile Schengen system, which embodies all the weaknesses of the EU's complex security arrangements. 
endangered not only European cohesion generally but the cohesion of the ECE region in particular, including the domestic socio-economic and political cohesion of individual ECE states. The latest International Monetary Fund (IMF) regional report investigates how ECE countries have been "weathering the internal and external shocks" and concludes that after the global crisis, "convergence is effectively off the fast track"; IMF notes that the reason for this "growth slowdown is thought to be structural" (IMF 2016). This IMF report follows a World Economic Forum (WEF) analysis which links the worsening competiveness of all five ECE countries (the Czech Republic, Hungary, Poland, Slovakia and Slovenia) primarily to the weaknesses of their institutions and human capital. The IMF's recommendations for ECE structural reforms therefore concern the institutional sector, which has been deeply and organically connected with investments in human capital (IMF 2016: 21,45,50; see also IMF 2014a, b).$^{16}$

It is clear from the recent IMF report that ECE countries have maintained the traditional GDP-based model of economic development which managed to produce a modest catch-up effect for some years. They have not, however, been able to switch to the newer innovation-driven model based on investments in human capital, as advertised by the EU in its EU2020 Strategy (see WEF 2012). As such, they have avoided making painful structural reforms to their institutional systems, and this weakness of ECE institutions points to the reason for both the economic slowdown and the decline of democracy in the region - that is to say, for its deconsolidation process. It is indeed shocking to contrast the general rankings of ECE countries with their institutional rankings on the one hand and their development of human capital through education and innovation ( $R \& D$ ) on the other. This contrast is, however, also the key to understanding ECE's declining competitiveness. A similar pattern can be observed in Bertelsmann's country reports on the gap between the situation index (SI), which indicates the general development level, and the management index (MI), which denotes the specific level of good governance or governmental capacity in the given ECE state. ${ }^{17}$

The WEF's "economic" reports have turned increasingly into social and political reports as commentators search for reasons for the global competitive-

16 The WEF sets out a total of 12 pillars which effectively cover all areas of socio-economic life. In particular, the four "basic requirements" for competitiveness within the WEF concern (1) institutions, (2) infrastructure, (3) the macroeconomic environment and (4) health and primary education. In addition, there are six "efficiency enhancers", which relate to higher education with (2-6) five market efficiency factors. Finally, two "innovation and sophistication factors" refer to (1) business sophistication and (2) innovation. The BF country reports make the same effort to reflect the complexity of all social factors. BF's social reports are especially helpful in this respect.

17 The overall Bertelsmann rankings for ECE countries and their institutions were as follows in 2015: Czech Republic: 31-57, Hungary: 63-97, Poland: 41-58, Slovenia: 59-67, Slovakia: 67-104. According to the 2016 $\mathrm{BF}$ country reports, the difference between SI and MI in Hungary was 12-76 while in the Czech Republic, it was 3-12 and in Slovenia, it was 7-18 (see BF 2016). It is no coincidence that the Worldwide Governance Indicators (WGI, World Bank 2015) showed a sharp decline in good governance in ECE in this period. 
ness of individual countries. The WEF has, in fact, developed a 12-pillar system covering all dimensions of social life from institutions to innovation, and this goes far beyond the simplified model of GDP-based economic growth. The new policy-development paradigm - which I have referred to here as MDG - is in tune with the above-discussed third democracy debate that focuses on the quality of democracy and the effective workings of democracy as the basis for global competitiveness. Under this new approach, economic growth is not reduced to GDP but seen as an innovation-driven development. This presupposes above all that there is (1) comprehensive institution-building with good governance and a high level of administrative capacity and (2) extensive reproduction of human capital through good (higher level) education with a substantial research and innovation capacity in the given country.

Institutions and human capital have been the big losers over the last quarter century in ECE, and the global crisis is just the latest blip in this negative process. ECE countries have avoided making structural reforms to the elite democracy system in general and to government operations in particular. Moreover, investment in human capital has been neglected over the last 25 years to that extent that there is now an "innovation divide" in the EU (Veugelers 2016). Based on the impact of the triple crisis, the internal cohesion of these "low trust" countries has here been seriously reduced along the following lines: (1) instead of economic cohesion, dual economies have emerged, (2) instead of social cohesion, social polarisation has deepened and (3) instead of territorial cohesion, the ECE countries have split into two - developed and underdeveloped - parts (western East vs. eastern East). At the same time, the cumulative neglect of human capital has eroded binding and bridging social capital along with trust in ECE social and political institutions. The majority of ECE populations have, thus, experienced a dramatic loss of social security while an economic and political internal de-securitisation process has also been unleashed. In the final analysis, social insecurity and social deficits in the areas of jobs, income, status and identity have produced a precarious situation across all - young, middle-aged and older - generations in the region. This cumulative "social deficit" (Aniol 2015) is the key to understanding the disillusionment and resentment that have produced a golden age of populism with the deconsolidation of democracy.

All in all, the ECE countries have undergone a historical process of social, economic and political de-securitisation in which a downward spiral or vicious circle of negative processes have reinforced each other. As such, there has been dramatic political destabilisation with a total loss of public trust in ECE political elites and institutions. We may, thus, understand the socio-political crisis discussed in the first part of this study as a process of internal deconsolidation with cumulative effects which are now registering in the initial stage of the NWO. 
In what follows, I consider the external deconsolidation of the ECE region as a virtual "sunken continent."18

\section{The sunken continent: The external deconsolidation of ECE under the NWO}

Drastic changes in global security and the global economy, both subsystems of the world system, have demonstrated the specific roles of these subsystems in the ongoing transition between the two world orders. Of the two, the security framework is the more rigid, comprising geopolitical networks and power positions on the global map. The global security system breaks down quickly and changes suddenly but may then remain quite stable for longer periods. In contrast, other subsystems like the global economy with its social (employment and income) structures, usually change more slowly and continuously; they also regularly produce smaller crises requiring adjustments. The latest Kondratieff half-century long cycle, which started around 1990, reached its internal turning point in 2015. In keeping with this, the bipolar security system collapsed in 1990, turning into a tripolar system composed of the USA and EU with some vague roles for BRIC countries. In 2015, that tripolar system became more multi-polar after an aggressive comeback by Russia and the entry of China as well as new claims by regional powers like India, Turkey, Iran and Brazil. ${ }^{19}$

These specificities of the changing world order have, however, long been neglected in European Studies discussions of global regionalisation in continent-size mega-regions like the EU. The collapse of the bipolar system meant the devaluation of traditional military security and the disappearance of the geopolitical dimension from strategic thinking during the OWO. The emergence of the current system of the NWO has brought the return of military security, which is combined now with new dimensions like energy and cyber-security. Moreover, the character of wars has changed beyond recognition, as we may see from wars by proxy and hybrid wars that have activated long-term frozen conflicts, and this has generally provoked terrorism at a global level. In fact, the meaning of "security" is now changing constantly both in terms of "hard" forms of traditional-military security and "soft" forms of emerging energy, cyber-

18 The 2015 rankings of World Economic Forum (WEF 2015) demonstrate this political destabilisation, as seen primarily in the areas of (1) diversion of public funds, (2) public trust in politicians and (3) transparency of government decision-making. See the first pillar (institutions) of the detailed rankings of the Global Competitiveness Index country reports: Czech Republic (CZ: 92-107-88), Hungary (HU: 119-120-119), Poland (PL: 48-100-106), Slovenia (SI: 70-105-71) and Slovakia (SK: 127-113-79). In this respect, the ECE countries fall within the lowest third of the 148 states ranked by WEF.

19 The discussion in this section is a short summary of my recent security-related publications (Ágh 2016a, $b, c)$, which deal with the securitisation of the ECE region in the NWO based on the changes in the Visegrad Group (V4) and the EaP crisis. The economic development of the BRICs has recently suffered a significant setback and as a result their position in the NWO has decline. This topic, however, like Russia's expansionism in the Balkan and EaP regions, is beyond the topic of this paper. 
-digital, climate or "green" security. There are many other types of soft security in the form of "financial" security, including the control of black money transfers and money laundering or global human trafficking, and all of these forms presuppose new roles for security services. At present, we are, thus, experiencing securitisation as a process of complex security arrangements. The coordination of these overlapping and conflicting hard and soft security dimensions has created a tremendous task for all mega-regions under the NWO. More specifically, it has produced a "polycrisis" based on the huge overload of crisis management, geopolitical strategy and security governance for the EU.

As globalisation now stands, the entire multi-level nested game has appeared in the form of a new regionalisation, resulting in the territorialisation of EU crisis management across different levels. This basically means a division among (1) the EU as a mega-region in the world system, (2) macro-regions like ECE and (3) individual member states. As a mega-region, the EU initiated regionalisation in its neighbourhood under the European Neighbourhood Policy (ENP) in the 2000s. Nevertheless, the EU could not cope with the ensuing challenges - among them, the "carrot crisis" on one hand and over-demanding and underperforming neighbours on the other - as the failure of the Arab Spring and Eastern Partnership (EaP) crisis demonstrated. In the mid-2010s, the geopolitical situation changed drastically around the EU's eastern and south-eastern borders, producing a serious challenge for the entire EU28 and the ECE region in particular, with direct concerns for some countries. In the current "New Cold War," to use the words of Russian Prime Minister Dmitry Medvedev, the securitisation of European governance in MDG and MLG terms has occurred through the coordination of several policy fields and territorialisation of security governance - a process that has so far had little success. This new security governance includes renewed external governance in the EaP and West Balkan macro-regions since with the comeback of geopolitics, dormant and frozen conflicts have been activated in the EU's "near abroad," mostly due to Russian expansionism and the Ukrainian crisis.

The EU securitisation process can also be understood via a short history of EU regionalisation-territorialisation under the MLG paradigm. Regarding the regional structure of a cohesive Europe, there have been three periods of development of an EU spatial system serving as the middle layers between the EU and its member states. The first, which we may call the "Europe of regions," occurred when the NUTS2 meso-regions covered the whole map of the EU as sub-national territorial levels. This eventually led to the formal-legal extension of EU cohesion policy so as to include the territorial cohesion of these regions under the Lisbon Treaty after their economic and social cohesion. The second period involved the organisation of functional macro-regions in the 2000s, starting with the emergence of the Baltic Sea Region (EUSBSR) and the Danube Strategy (EUSDR). While these functional regions had both historical 
and structural-practical roles, their innovative years are now over. Nevertheless, this regionalisation has generated its own map of a cohesive Europe. This stage of regionalisation has also had implications for a wider Europe based on the intensive contact between the two macro-regions above and their meso-regions, and the West Balkans and Eastern Partnership. The third period has seen the emergence of a multi-floor Europe based on the "re-structuring" of the core-periphery divide during the global crisis and subsequent geopolitical crisis. Due to the aggressive pressure of the geopolitical crisis on its eastern and south-eastern borders, the EU has "(re)discovered" geopolitics (Kagan 2015). Along these lines, a new regionalisation has taken place in the EU, producing geopolitical regions of some kind under the NWO. The same applies to the ECE region though it remains poised halfway between being a functional region and being a geopolitical region and is, thus, at a critical juncture in many respects. In sum, the initial phases of securitisation have occurred at all the three levels of the EU, i.e. affecting the EU as a whole (mega-region), its geopolitical regions (macro-regions) and its member states in particular locations.

While the various dimensions of securitisation have impacted differently on the EU's emerging geopolitical macro-regions, the effect on the ECE region has clearly been very serious. The macro-region of ECE - and on a wider view, the NMS - is now at a crossroads with the destabilising effects of global politics appearing at its borders just as this region recognises the failure of the catch-up process. Thus, instead of a "return to Europe," the new strategy in the region is a return to the past based on a traditionalist-nativist mindset. The ECE countries regained their full national sovereignty from the Soviet Union after the collapse of the bipolar world, and for them, real national sovereignty in the form of "independence" remains a delicate issue. These states have conceptualised their national identity as a permanent fight with foreign powers for their national sovereignty over the course of history. On this basis, ECE's newly emerging "de-democratised" regimes (or, if you like, incompetent "de-Europeanised" governments) have murmured the "sovereignty" mantra whenever the EU calls on them to take common actions in the current geopolitical crisis. While the ECE countries have over-played national sovereignty in this geopolitical crisis, the neglect of the particular features of the crisis in the ECE region may ultimately prove counter-productive for the EU as a whole in a kind of "revenge of geopolitics" (Nodia 2014). This new vicious circle of internal and external deconsolidation has further disturbed EU operations while strengthening the domestic positions of (semi)-authoritarian leaders in ECE. ${ }^{20}$

20 Taking their own approach to securitisation, the V4 have actually developed several alternative formations including the V4+ or V4+B3 (meaning the three Baltic states), which aims to ensure the V4's efforts cover the whole NMS region to some extent (see Törő et al. 2014). On the unholy or authoritarian alliance of the V4, see, e.g., Dostál (2015), Kucharczyk - Meseznikov (2015), Parkes (2014) and Visvizi - Stępniewski (2013). 
In fact, just as EU authorities failed to confront growing ECE divergence during the earlier and far more favourable OWO stage, they are now responsible for the even greater neglect of this divergence during the polycrisis of the NWO. The EU must ultimately face this new round of negative divergence from ECE governments and at least take efficient measures against serious violations of European rules and values. The acuteness of the danger has been quite obvious since Poland's recent turn in a populist-authoritarian direction. Under the pressure of the refugee crisis, the Visegrád Four (V4) - the security organisation of ECE countries - has formed some kind of unholy alliance within the EU in a controversial new instance of ECE regional cooperation. Originally, many had expected that the Europeanisation of ECE countries would lead to more regional convergence within the mainstream EU and provide a common "voice" for the proper representation of these states' interests in the EU transnational decision-making system. Ironically, however, the earlier divergences among the ECE countries have turned to tentative convergence because of the impact of the new "negative externality" of the geopolitical crisis. ${ }^{21}$

Following the dual - Ukrainian and refugee - crises of the New Cold War, ECE countries have achieved greater regional cohesion in opposing mainstream EU policies despite their remaining idiosyncrasies. Faced with the common pressures of Russian interventionism and the refugee crisis, these countries have come closer to taking a common stand, which has characteristically diverged from the EU mainstream approach in its geopolitical strategy. The new attitude manifesting in V4 declarations is double-edged. It shows the slow and contradictory regionalisation of these states but it also points to the danger of their further marginalisation as they increasingly turn away from mainstream EU developments. All in all, this extreme case of negative differentiated integration has had a serious impact on the EU as a whole and an even more devastating effect on the ECE region. Moreover, its destabilising effects can be understood as part of a complex externally/geopolitically-driven deconsolidation process or international "de-securitisation" of this virtual sunken continent. ${ }^{22}$

\section{A brief conclusion: High time for re-democratisation and "securitisation"}

By the mid-2010s, it was clear that the ECE countries had failed at their first try at democratisation, Europeanisation and the "convergence dream" (Darvas 2014) under the favourable conditions of the Old Word Order. Today, these

21 The European Policy Centre identifies the new authoritarian leaders as "troublemakers" in the area of foreign policy; see EPC (2016).

22 The Economist (2016) describes the new orientation of the V4 organisation as "[b]ig, bad Visegrad" in "illiberal Central Europe." 
states must begin their second attempt under the unfavourable conditions of the New World Order, which has converged with the geopolitical crisis. There are, however, some lessons to draw from the region's failed elite democracies and national resistance to structural reforms in the EU - that is, from de-democratisation and de-Europeanisation - if we are to understand the main reasons for ECE's historical divergence. It is true that outside the dominant positive externalities driving Europeanisation and democratisation, negative externalities of the EU have also had toxic effects. These effects have played a role in this negative historical trajectory of ECE since some of the EU's modernising effects have appeared at the core and not on the periphery. In general, the EU's failure to take effective measures against violations of European rules and values in ECE countries remains a key issue.

The ECE region is now facing a deconsolidation and de-securitisation process driven from both outside and inside. On top of the external pressures of geopolitical tensions, there are the internal pressures of authoritarian regimes, exhausted societies and non-competitive economies. The situation clearly shows the long-term limits of the EU's "transformative power" as well as the failure of recent security governance in a systemic misfit/mismatch. The vital issue is now whether these states can stop and turn back a process of increasing marginalisation, or the core-periphery divide will further weaken the ECE region, rendering it a sunken continent in the EU. ${ }^{23}$

Just as the management of the Eurozone crisis was pressing on the EU in 2010 during the economic-financial global crisis, the EU's top challenge in 2016 is management of a security crisis based on a new and complex understanding of security. At present, the EU's capacity for crisis management is overloaded given the crisis over crisis management (polycrisis) that has appeared together with the failure of balanced integration in a Europe where cohesion is deeply eroded. These events have only widened the split between the core and the periphery. Extending into the second half of the 2010s, the biggest challenge for the ECE countries is, thus, two-fold: they must regain their external security through intensive cooperation within the EU; and, at the same time, they must restore their internal security through "re-democratisation." The latter is a bottom-up process that could replace the failed top-down elite democracies in these countries.

23 There is extensive academic literature on the limits of the EU's transformative power. See, e.g., Grabbe (2014). 


\section{References}

Aniol, Wlodzimierz (2015): A Social Deficit: Poland in the Face of Developmental Challenges in the 2010s. Problems of Social Policy (Warsaw) 31 (4): 39-56.

Ágh, Attila (2015a): De-Europeanization and de-Democratization trends in ECE: From the Potemkin democracy to the elected autocracy in Hungary. Journal of Comparative Politics 8 (2): 4-26.

Ágh, Attila (2015b): The Triple Crisis in the New Member States: The historical trajectory of NMS-8 in the Past Quarter Century. Southeastern Europe 39 (3): 294-317.

Ágh, Attila (2015c): Radical party system changes in five East-Central European states: Eurosceptic and populist parties on the move in the 2010s. Baltic Journal of Political Science 4 (4): 23-48.

Ágh, Attila (2016a) "The increasing core-periphery divide and the new member states: Diverging from the European Union's mainstream developments,"117-129, in Magone et al., eds.: Core-periphery Relations in the European Union, London and New York: Routledge, 332.

Ágh, Attila (2016b): The 'securitization' of the EaP policy in the EU: The External Europeanization in the Wider Europe. Journal of Comparative Politics 9 (1): 36-58.

Ágh, Attila (2016c): Core-Periphery divides in the EU transformation crisis: The regional challenge of the Visegrad Four. Security Dimensions of Central and Eastern Europe, Yearbook of the Institute of East-Central Europe (Warsaw), 14 (1): 11-25.

Balfour, Rosa - Stratulat, Corina (2012): The enlargement of the European Union, EPC Discussion Paper, 10 December, http://www.epc.eu/documents/uploads/pub_3176_enlargement_ of_the_eu.pdf (12 December 2016).

Banac, Ivo (2014): Twenty-Five Years after the Fall of the Berlin Wall. East European Politics and Societies and Cultures, Special Issue on the Post-1989 Developments in the Region, 28 (2): 653-657.

Bogaards, Matthijs (2009): How to classify hybrid regimes? Defective democracy and electoral authoritarianism. Democratization, 16 (2): 399-423.

Bertelsmann Foundation (BF) (2015a): Next Generation Democracy, www.nextgenerationdemocracy.org and http://www.bti-project.org/next-generation-democracy (12 December 2016).

Bertelsmann Foundation (BF) (2015b): Social Justice in the EU - Report 2015, Social Inclusion Monitor Europe (SIM), http://www.social-inclusion-monitor.eu/social-justice-index/ (12 December 2016).

Bertelsmann Foundation (BF) (2015c): Social Policy Reforms in the EU: A Cross-national Comparison, Social Inclusion Monitor Europe (SIM) - Reform Barometer, http://www.social-inclusion-monitor.eu/reform-barometer/ (12 December 2016).

Bertelsmann Foundation (BF), BTI (2016a) Hungary country report, http://www.bti-project.org/ en/reports/country-reports/country-reports/itc/HUN/ (12 December 2016).

Bertelsmann Foundation (BF), BTI (2016b) Poland country report, https://www.bti-project.org/ fileadmin/files/BTI/Downloads/Reports/2016/pdf/BTI_2016_Poland.pdf (12 December 2016).

Biscop, Sven (2015): Global and Operational: A New Strategy for EU Foreign and Security Strategy, Egmont Institute, http://www.egmontinstitute.be/wp-content/uploads/2015/09/ iaiwp1527-def.pdf (12 December 2016). 
Cassani, Andrea (2014): Hybrid what? Partial consensus and persistent divergences in the analysis of hybrid regimes, International Political Science Review 35 (5): 542-558.

Chadwick, Vince (2016): "Putin-like?" Not us, say Poland and Hungary in response to Bill Clinton. Politico, 17 May, http://www.politico.eu/article/us-democracy-putin-like-not-us-say-poland-and-hungary-in-response-to-bill-clinton/ (12 December 2016).

Coman, Ramona - Tomini, Luca (2014): A Comparative Perspective on the State of Democracy in Central and Eastern Europe. Europe-Asia Studies 66 (6): 853-858

Coppedge, Michael et al. (2011): Conceptualizing and Measuring Democracy: A New Approach. Perspectives on Politics, Vol. 9, No. 2, June, http://people.bu.edu/jgerring/documents/MeasuringDemocracy.pdf.

Dahrendorf, Ralf (1990) Reflections on the Revolutions in Europe, Transaction Books, p. 178

Darvas, Zsolt (2014): The convergence dream 25 years on, http://www.bruegel.org/nc/blog/ detail/article/1528-the-convergence-dream-25-years-on/ (12 December 2016).

Denk, Thomas - Silander, Daniel (2012): Problems in Paradise? Challenges to future democratization in democratic states. International Political Science Review, 33 (1): 25-40.

Dzihic, Vedran (2014): Grey zones between democracy and authoritarianism: Re-thinking the current state of democracy in Eastern and South Eastern Europe, in Wiersma et al., eds. (2014) Problems of Representative Democracy in Europe, Amsterdam: Foundation for European Progressive Studies: 21-32.

European Commission (EU) (2014a): A new EU Framework to strengthen the Rule of Law, Brussels, 11. 3. 2014, $\operatorname{COM}(2014) 158$ final.

European Commission (EC) (with Transparency International) (2014b): EU Anti-Corruption Report, Brussels, 3. 2. 2014, COM(2014) 38 final, http://ec.europa.eu/dgs/home-affairs/e-library/documents/policies/organized-crime-and-human-trafficking/corruption/docs/acr_2014_en.pdf.

The Economist Intelligence Unit (EIU) (2015): Democracy Index 2014, http://www.eiu.com/public/ thankyou_download.aspx?activity=download \& campaignid=Democracy0115.

European Policy Centre (2016) (EPC): Europe's Troublemakers: The Populist Challenge to Foreign Policy, February 2016, p. 59, http://www.epc.eu/documents/uploads/pub_6377_europe_s_ troublemakers.pdf.

Epstein, Rachel - Jacoby, Wade (2014): Eastern Enlargement Ten Years On: Transcending the East-West Divide? Journal of Common Market Studies, 52 (1) special issue: Eastern Enlargement Ten Years On: 1-16

Euractiv (2014): Brussels lays out plans to counter 'systemic threats' to EU rule of law, 12 March, http://www.euractiv.com/section/justice-home-affairs/news/brussels-lays-out-plans-to-counter-systemic-threats-to-eu-rule-of-law/.

Freedom House (FH) (2016a): Nations in Transit 2016, https://freedomhouse.org/sites/default/ files/FH_NIT2016_Final_FWeb.pdf (12 December 2016).

Freedom House (FH) (2016b): Freedom in the World 2016, https://freedomhouse.org/report/ freedom-world/freedom-world-2016 (12 December 2016). 
Freedom House, Nations in Transit (2016c): Hungary, https://freedomhouse.org/report/nations-transit/2016/hungary (12 December 2016).

Freedom House, Nations in Transit (2016d): Poland, https://freedomhouse.org/report/nations-transit/2016/poland (12 December 2016).

International Labor Organization (2016): Crisis has aggravated long-term erosion of European middle class, http://www.ilo.org/brussels/press/press-releases/WCMS_455743/lang--en/index. htm (12 December 2016).

International Monetary Fund (IMF) (2014a): Central, Eastern, and Southeastern Europe, Regional Economic Issues Update, October, http://www.imf.org/external/pubs/ft/reo/2014/eur/eng/ pdf/erei1014.pdf (12 December 2016).

International Monetary Fund (IMF) (2014b): 25 Years of Transition, Post-Communist Europe and the IMF, Regional Economic Issues, Special Report, October, http://www.imf.org/external/ pubs/ft/reo/2014/eur/eng/pdf/erei_sr_102414.pdf (12 December 2016).

International Monetary Fund (2016): Regional Economic Issues: Central, Eastern and Southeastern Europe, May, http://www.imf.org/external/pubs/ft/reo/2016/eur/eng/pdf/rei0516. pdf (12 December 2016).

Innes, Abby (2014): The Political Economy of State Capture in Central Europe. Journal of Common Market Studies, 52 (1), special issue “Eastern Enlargement Ten Years On: 88-104

Juncker, Jean-Claude (2016): Norbert Schmelzer lecture on 3 March, http://www.universiteitleiden.nl/en/news/2016/03/five-ll.m-students-attended-the-2016-norbert-schmelzer-lecture-given-by-commission-president-jean-claude-juncker (12 December 2016).

Kagan, Robert (2015): The weight of geopolitics. Journal of Democracy 26 (1), special issue: Is Democracy in Decline?: 21-31.

Köllner, Patrick - Kailitz, Steffen, eds. (2013) Democratization 20 (1), Special Issue Unpacking Autocracies: Explaining Similarity and Difference: 178.

Kucharczyk, Jacek - Meseznikov, Grigorij, eds. (2015) Diverging Voices, Converging Policies: The Visegrad States' Reactions to the Russia-Ukraine Conflict, Prague and Warsaw: Heinrich Böll Stiftung, p. 216.

Lessenski, Marin, ed. (2014): The Gravity Effect: Findings of the European Catch-Up Index 2014, European Policies Initiative-Open Society Institute, December 2014, http://eupi.osi.bg/cgi-bin/e-cms/vis/vis.pl?s=001 \& p=0070 \& g.

Magone, José, Laffan, Brigid -Schweiger, Christian, eds. (2016): Core-periphery Relations in the European Union, London and New York: Routledge, 332.

Merkel, Wolfgang (2004): Embedded and Defective Democracies. Democratization 11 (5): 3358.

Merkel, Wolfgang (2008): Plausible Theory, Unexpected Results: The Rapid Democratic Consolidation in Central and Eastern Europe. International Politics and Society (2): 11-29

Moeller, Joergen - Skaaning, Svend-Erik (2013): Autocracies, democracies, and the violation of civil liberties, pp. 82-106, in Köllner, Patrick - Kailitz, Steffen, eds. Democratization 20 (1), Special issue: Unpacking Autocracies: Explaining Similarity and Difference, 178.

Nodia, Ghia (2014): The revenge of geopolitics. Journal of Democracy 25 (4): 140-150. 
Noutcheva, Gergana (2016): Societal Empowerment and Europeanization: Revisiting the EU's Impact on Democratization. Journal of Common Market Studies 54 (3): 691-708.

Offe, Claus (1991): Capitalism by Democratic Design? Democratic Theory facing the Triple Transition in East Central Europe. Social Research 38 (4): 863-881.

Offe, Claus and Pierre Adler (2004): Capitalism by Democratic Design? Democratic Theory facing the Triple Transition in East Central Europe. Social Research 71 (3): 501-528.

Orbán, Viktor (2014): The End of Liberal Democracy, Talk on 26 July, http://www.freehungary. hu/index.php/56-hirek/3123-full-text-of-hungary-pm-viktor-orban-s-scandalous-speech-at-the-xxv-balvanyos-free-summer-university-and-youth-camp (12 December 2016).

Organization for Security and Co-operation in Europe (OSCE), Office for Democratic Institutions and Human Rights (2014): Hungary, Parliamentary Elections, 6 April, Final Report, http://www. osce.org/odihr/elections/hungary/121098?download=true (12 December 2016).

Papadopoulos, Yannis (2013): Democracy in Crisis? Politics, Governance and Policy, Houndmills: Palgrave-Macmillan, 296.

Pappas, Takis (2014): Populist Democracies: Post-Authoritarian Greece and Post-Communist Hungary. Government and Opposition 49 (1): 1-25.

Przeworski, Adam (1995): Sustainable Democracy, Cambridge University Press, 156.

Rupnik, Jacques (2007): From Democracy Fatigue to Populist Backlash. Journal of Democracy 18 (4) special issue: Is East-Central Europe Backsliding?: 17-25.

Rupnik, Jacques (2012): Hungary's Illiberal Turn: How Things Went Wrong. Journal of Democracy 23 (3): 132-137.

Rupnik, Jacques - Zielonka, Jan (2013): The State of Democracy 20 Years On: Domestic and External Factors. East European Politics and Societies 27 (3), special issue: The State of Democracy 20 Years On: 1-25.

Solana, Javier (2016): Hungary's EU membership would be rejected today, Politico, 5 May, http:// www.politico.eu/article/hungarys-eu-membership-would-be-rejected-today-former-nato-chief-javier-solana/ (12 December 2016).

The Economist (2016): Illiberal Central Europe: Big, bad Visegrad, 30 January, http://www. economist.com/news/europe/21689629-migration-crisis-has-given-unsettling-new-direction-old-alliance-big-bad-visegrad (12 December 2016).

Tomini, Luca (2014): Reassessing Democratic Consolidation in Central and Eastern Europe and the Role of the EU. Europe-Asia Studies 66 (6): 859-891.

Törő, Csaba, Butler, Eamonn - Grúber, Károly (2014): Visegrád: The Evolving Pattern of Coordination and Partnership After EU Enlargement. Europe-Asia Studies 66 (3): 364-393, V4+ and V4+B3 formations.

Veugelers, Reinhilde (2016): The European Union's growing innovation divide, Bruegel, Issue 8, April, http://bruegel.org/2016/04/the-european-unions-growing-innovation-divide/.

World Economic Forum (2012): The Europe 2020 Competitiveness Report: Building a More Competitive Europe, http://www3.weforum.org/docs/CSI/2012/Europe2020_Competitiveness_Report_2012.pdf (12 December 2016). 
World Economic Forum (WEF) (2015) Global Competitiveness Report 2015-2016, http://www3. weforum.org/docs/gcr/2015-2016/Global_Competitiveness_Report_2015-2016.pdf(12 December 2016).

World Bank (2015) Worldwide Governance Indicators (WGI), http://info.worldbank.org/governance/wgi/index.aspx\#reports (12 December 2016).

Wiersma, Jan Marius, Stetter, Ernst - Schublach, Ernst, eds. (2014) Problems of Representative Democracy in Europe, Amsterdam: Foundation for European Progressive Studies, p. 208.

\section{Annex}

\section{Tables concerning continental New Member States (NMS-8)}

Table 1: EIU - democracy rankings and overall score on a 1-10 scale (10-best) The Economist Intelligence Unit (167 countries)

\begin{tabular}{|c|c|c|c|c|c|c|}
\hline & 2006 & 2008 & 2010 & 2011 & 2012 & 2014 \\
\hline BG & $49-7.10$ & $52-7.02$ & $51-6.84$ & $52-6.78$ & $54-6.72$ & $55-6.73$ \\
\hline CZ & $18-8.17$ & $19-8.19$ & $16-8.19$ & $16-8.19$ & $17-8.19$ & $25-7.94$ \\
\hline HR & $51-7.04$ & $51-7.04$ & $53-6.81$ & $53-6.73$ & $50-6.93$ & $50-6.93$ \\
\hline HU & $38-753$ & $40-7.44$ & $43-7.25$ & $49-7.04$ & $49-6.96$ & $51-6.90$ \\
\hline PL & $46-7.30$ & $45-7.30$ & $48-7.05$ & $45-7.12$ & $44-7.12$ & $40-7.47$ \\
\hline RO & $50-7.06$ & $50-7.06$ & $56-6.60$ & $59-6.54$ & $59-6.54$ & $57-6.68$ \\
\hline SI & $27-7.96$ & $30-7.96$ & $32-7.69$ & $30-7.76$ & $28-7.88$ & $37-7.57$ \\
\hline SK & $41-7.40$ & $44-7.33$ & $38-7.35$ & $38-7.35$ & $40-7.35$ & $45-7.35$ \\
\hline
\end{tabular}

Table 2: NIT Independent media ratings, 2005-2014 (1-best) Freedom House

\begin{tabular}{|c|c|c|c|c|c|c|c|c|c|}
\hline & 2005 & 2007 & 2009 & 2011 & 2013 & 2014 & 2015 & 2016 & Rank \\
\hline BG & 3.50 & 3.50 & 3.75 & 3.75 & 4.00 & 4.00 & 4.00 & 4.00 & 78 \\
\hline CZ & 2.00 & 2.25 & 2.25 & 2.50 & 2.50 & 2.75 & 2.75 & 2.75 & 28 \\
\hline HR & 3.75 & 4.00 & 4.00 & 4.00 & 4.00 & 4.00 & 4.00 & 4.00 & 84 \\
\hline HU & 2.50 & 2.50 & 2.50 & 3.25 & 3.50 & 3.50 & 3.75 & 3.75 & 78 \\
\hline PL & 1.50 & 2.25 & 2.00 & 2.25 & 2.50 & 2.50 & 2.50 & 2.75 & 51 \\
\hline RO & 4.00 & 3.75 & 3.75 & 4.00 & 4.25 & 4.25 & 4.25 & 4.25 & 74 \\
\hline SI & 1.50 & 2.00 & 2.25 & 2.25 & 2.25 & 2.25 & 2.25 & --- & 33 \\
\hline SK & 2.25 & 2.25 & 2.75 & 3.00 & 2.75 & 2.75 & 3.00 & 3.00 & 38 \\
\hline
\end{tabular}

Ranking: Global ranking in 2016 
Table 3: Social Justice Index 2015, rankings of NMS-8 (28 countries) Bertelsmann Foundation

\begin{tabular}{|c|c|c|c|c|c|c|c|c|}
\hline & rank & PP & EE & LA & SC & HE & IJ & MP \\
\hline BG & 26 & 28 & 23 & 20 & 26 & 25 & 16 & 28 \\
\hline CZ & 5 & 1 & 11 & 10 & 14 & 5 & 9 & 12 \\
\hline HR & 22 & 23 & 3 & 25 & 26 & 18 & 21 & 22 \\
\hline HU & 23 & 24 & 19 & 18 & 24 & 23 & 23 & 26 \\
\hline PL & 15 & 16 & 8 & 19 & 14 & 26 & 10 & 18 \\
\hline RO & 27 & 27 & 24 & 21 & 25 & 28 & 17 & 27 \\
\hline SI & 9 & 11 & 7 & 17 & 9 & 14 & 6 & 11 \\
\hline SK & 17 & 6 & 28 & 26 & 20 & 21 & 18 & 15 \\
\hline
\end{tabular}

$\mathrm{PP}$ - poverty prevention, EE - equitable education, LA - labour market access

SC - social cohesion, HE - healthcare, IJ - inter-generational justice

$\mathrm{MP}$ - severe material deprivation

Table 4: Global Competitiveness Index (GCI) 2005-2015 (Rankings of 122-148 countries)

World Economic Forum

\begin{tabular}{|c|c|c|c|c|c|c|c|c|c|c|c|}
\hline & 2005 & 2006 & 2007 & 2008 & 2009 & 2010 & 2011 & 2012 & 2013 & 2014 & 2015 \\
\hline BG & 61 & 72 & 79 & 76 & 76 & 71 & 74 & 62 & 57 & 54 & 54 \\
\hline CZ & 29 & 29 & 33 & 33 & 31 & 36 & 38 & 39 & 46 & 37 & 31 \\
\hline HR & 64 & 51 & 57 & 60 & 61 & 76 & 80 & 81 & 75 & 77 & 77 \\
\hline HU & 35 & 41 & 47 & 62 & 58 & 52 & 48 & 60 & 63 & 60 & 63 \\
\hline PL & 43 & 48 & 51 & 53 & 46 & 39 & 41 & 41 & 42 & 43 & 41 \\
\hline RO & 67 & 68 & 74 & 68 & 64 & 67 & 77 & 78 & 76 & 59 & 53 \\
\hline SI & 30 & 33 & 39 & 42 & 37 & 45 & 57 & 56 & 62 & 70 & 59 \\
\hline SK & 36 & 37 & 41 & 46 & 47 & 60 & 69 & 71 & 78 & 75 & 67 \\
\hline
\end{tabular}

World Economic Forum (WEF) (2015) Global Competitiveness Report 2015-2016, http://www3.weforum.org/ docs/gcr/2015-2016/Global_Competitiveness_Report_2015-2016.pdf

Table 5: Rankings of institutions (1st pillar), NMS-8 between 2008 and 2015 World Economic Forum (Rankings of 134-148 countries)

\begin{tabular}{|c|c|c|c|c|c|c|}
\hline & 2008 & 2011 & 2012 & 2013 & 2014 & 2015 \\
\hline BG & 111 & 110 & 108 & 107 & 112 & 107 \\
\hline CZ & 72 & 84 & 82 & 86 & 76 & 57 \\
\hline HR & 74 & 90 & 96 & 93 & 87 & 89 \\
\hline HU & 64 & 73 & 80 & 84 & 83 & 97 \\
\hline PL & 88 & 52 & 55 & 62 & 56 & 58 \\
\hline RO & 89 & 99 & 116 & 114 & 88 & 86 \\
\hline SI & 49 & 55 & 58 & 68 & 75 & 67 \\
\hline SK & 73 & 101 & 104 & 119 & 110 & 104 \\
\hline
\end{tabular}

Global Competitiveness Report 2015-2016 
Table 6: Rankings for trust in politicians (in 1st pillar) NMS-8 between 2008 and 2015

World Economic Forum

\begin{tabular}{|c|c|c|c|c|c|c|}
\hline & $\mathbf{2 0 0 8}$ & $\mathbf{2 0 1 1}$ & $\mathbf{2 0 1 2}$ & $\mathbf{2 0 1 3}$ & $\mathbf{2 0 1 4}$ & $\mathbf{2 0 1 5}$ \\
\hline BG & 112 & 95 & 85 & 97 & 130 & 110 \\
\hline CZ & 117 & 134 & 139 & 146 & 138 & 107 \\
\hline HR & 79 & 104 & 115 & 114 & 124 & 122 \\
\hline HU & 94 & 130 & 128 & 129 & 113 & 120 \\
\hline PL & 113 & 76 & 90 & 100 & 101 & 100 \\
\hline RO & 106 & 119 & 133 & 141 & 109 & 112 \\
\hline SI & 47 & 96 & 116 & 133 & 133 & 105 \\
\hline SK & 115 & 132 & 136 & 139 & 121 & 113 \\
\hline
\end{tabular}

The Global Competitiveness Report 2015-2016

Table 7: Rankings in selected government fields in 2015 (in 1st pillar) World Economic Forum

\begin{tabular}{|c|c|c|c|}
\hline & Public funds & Favouritism & Transparency \\
\hline BG & 104 & 122 & 120 \\
\hline CZ & 92 & 94 & 88 \\
\hline HR & 84 & 100 & 113 \\
\hline HU & 119 & 125 & 119 \\
\hline PL & 48 & 69 & 106 \\
\hline RO & 97 & 111 & 84 \\
\hline SI & 70 & 97 & 71 \\
\hline SK & 127 & 138 & 79 \\
\hline
\end{tabular}

Global Competitiveness Report 2015-2016

(1) Diversion of public funds, (2) favouritism in government officials' decisions, (3) transparency of government decision-making

Table 8: Rankings of NMS-8 countries for innovation-driven development 2015

World Economic Forum

\begin{tabular}{|c|c|c|c|c|}
\hline & Institutions & Health and education & Higher education & Innovation \\
\hline BG & 107 & 53 & 64 & 94 \\
\hline CZ & 57 & 27 & 29 & 35 \\
\hline HR & 89 & 63 & 51 & 92 \\
\hline HU & 97 & 72 & 57 & 51 \\
\hline PL & 58 & 40 & 31 & 64 \\
\hline RO & 86 & 83 & 59 & 75 \\
\hline SI & 67 & 15 & 22 & 33 \\
\hline SK & 104 & 50 & 53 & 66 \\
\hline
\end{tabular}

Rankings in the 1st, 4th, 5th and 12th pillars

The Global Competitiveness Report 2015-2016 
Table 9: Rankings in education and innovation in 2015 World Economic Forum

\begin{tabular}{|c|c|c|c|c|c|}
\hline & Education & Talent-1 & Talent-2 & Innovation & R\&D \\
\hline BG & 93 & 133 & 132 & 79 & 78 \\
\hline CZ & 60 & 58 & 85 & 26 & 30 \\
\hline HR & 103 & 134 & 135 & 122 & 85 \\
\hline HU & 99 & 123 & 121 & 131 & 97 \\
\hline PL & 73 & 116 & 126 & 72 & 84 \\
\hline RO & 90 & 131 & 113 & 63 & 94 \\
\hline SI & 50 & 98 & 118 & 41 & 39 \\
\hline SK & 121 & 127 & 129 & 77 & 63 \\
\hline
\end{tabular}

(1) Quality of higher education system (in 5th pillar), (2) country's capacity to retain talent (in 7th pillar), (3) country's capacity to attract talent (in 7th pillar), (4) capacity for innovation (in 12th pillar) and (5) corporate spending on R \& D (in 12th pillar).

The Global Competitiveness Report 2015-2016

Table 10: EU2020: Overall rankings and scores of member states in 2010 and 2012 (7-best)

World Economic Forum (2012)

\begin{tabular}{|c|c|c|c|c|}
\hline & Rank 2010 & Score 2010 & Rank 2012 & Score 2012 \\
\hline BG & 27 & 3.79 & 27 & 3.76 \\
\hline CZ & 14 & 4.64 & 16 & 4.49 \\
\hline HR & -- & 4.1 & -- & 4.1 \\
\hline HU & 24 & 4.4 & 24 & 4.6 \\
\hline PL & 23 & 4.6 & 23 & 4.8 \\
\hline RO & 26 & 3.84 & 26 & 3.79 \\
\hline SI & 12 & 4.69 & 13 & 4.59 \\
\hline SK & 22 & 4.17 & 22 & 4.13 \\
\hline EU & -- & 4.94 & -- & 4.88 \\
\hline
\end{tabular}

(Sweden has the highest ranking: 5.77) 
Table 11: Smart EU2020: Rankings and scores of member states in 2012 (7-best)

World Economic Forum (2012)

\begin{tabular}{|c|c|c|c|c|c|c|c|c|c|c|}
\hline & rank & score & rank & score & rank & score & rank & score & rank & score \\
\hline BG & 26 & 3.69 & 24 & 3.65 & 26 & 4.30 & 26 & 2.96 & 27 & 3.95 \\
\hline CZ & 16 & 4.38 & 16 & 3.88 & 17 & 4.86 & 17 & 3.98 & 16 & 4.82 \\
\hline HR & -- & 3.86 & -- & 3.30 & -- & 4.72 & -- & 3.44 & -- & 4.27 \\
\hline HU & 22 & 4.60 & 23 & 3.61 & 21 & 4.60 & 20 & 3.53 & 23 & 4.61 \\
\hline PL & 21 & 4.90 & 22 & 3.65 & 23 & 4.44 & 22 & 3.39 & 14 & 4.89 \\
\hline RO & 27 & 3.64 & 26 & 3.44 & 27 & 4.80 & 27 & 2.89 & 26 & 4.14 \\
\hline SI & 15 & 4.41 & 19 & 3.73 & 16 & 4.88 & 15 & 4.80 & 13 & 4.95 \\
\hline SK & 24 & 3.91 & 20 & 3.70 & 24 & 4.34 & 25 & 3.23 & 25 & 4.36 \\
\hline EU & -- & 4.98 & -- & 4.26 & -- & 5.44 & -- & 4.90 & -- & 5.30 \\
\hline
\end{tabular}

Overall ranking; rankings for enterprise environment, digital agenda, innovative Europe and education, respectively (Sweden has the highest ranking: 5.76 )

Table 12: Inclusive EU2020: Rankings and scores of member states in 2012 (7-best)

World Economic Forum (2012)

\begin{tabular}{|c|c|c|c|c|c|c|}
\hline & rank & score & rank & score & rank & score \\
\hline BG & 26 & 3.98 & 15 & 4.32 & 27 & 3.64 \\
\hline CZ & 10 & 4.84 & 14 & 4.35 & 11 & 5.34 \\
\hline HR & -- & 3.89 & -- & 3.55 & -- & 4.24 \\
\hline HU & 21 & 4.24 & 22 & 3.97 & 21 & 4.52 \\
\hline PL & 25 & 3.99 & 19 & 4.10 & 24 & 3.97 \\
\hline RO & 24 & 4.20 & 20 & 4.00 & 23 & 4.30 \\
\hline SI & 14 & 4.73 & 16 & 4.26 & 14 & 5.19 \\
\hline SK & 20 & 4.35 & 24 & 3.92 & 18 & 4.78 \\
\hline EU & -- & 4.88 & -- & 4.33 & -- & 5.43 \\
\hline
\end{tabular}

Overall ranking and rankings for labour market, employment and social inclusion, respectively (Denmark has the highest ranking: 5.98)

Attila Ágh is a Professor in the Political Science Department at the Budapest Corvinus University. He was the founder and the former Head of Department of Political Science at this University, the Director of the Research Centre "Together for Europe" and also the President of the Central European Political Science Association (CEPSA). He was a visiting professor at many universities from Aarhus to Vienna, and also from New Delhi to Los Angeles. His major research interest is comparative politics with special regard to the EU developments, focusing the Europeanization and Democratization in the New Member States. He has published more than twenty books and dozens of papers in the international journals.Email: attila.agh@chello.hu. 